\title{
Rodent Malaria
}

\section{edited by $R$. Killick-Kendrick and $\mathbf{W}$. Peters}

September/October 1978, xxvi + 406 pp., f19.20/\$39.75

0.12 .407150 .3

Since the first isolation of a malaria parasite of a rodent thirty years ago, a great deal of research has been done on rodent malaria. This is principally because rodent malaria parasites provide a range of laboratory models which can be used to study almost all aspects of malaria relevant to the disease in man, with the great advantage that these parasites are more easily handled and cheaper than simian or avian parasites. In the last decade or so there has been a sudden increase in interest following the achievement of regular cyclical transmission of rodent malaria in the laboratory, and the discovery and isolation of new species and subspecies of parasites suitable for many new studies. The results of this research have been published in numerous papers scattered throughout many different journals, but this is the first book to provide a fully comprehensive review of the subject. Written by leading specialists in the field, the book provides a multidisciplinary approach to experimental malaria in rodents. Each chapter presents aspects of the parasites or the disease covered by a particular discipline, for example taxonomy, ecology, cell biology, biochemistry, genetics, immunology and chemotherapy. Such wide and authoritative coverage of the subject makes this a most important and up-to-date reference book for anyone interested in malaria of man or rodents, such as parasitologists, workers in tropical medicine and epidemiologists.

\section{Methods of Cultivating Parasites in Vitro}

\section{edited by Angela E. R. Taylor and John R. Baker} August 1978, xii + 302 pp., $£ 14.50 / \$ 30.00 \quad 0.12 .685550 .1$

This book is a completely rewritten version of the volume by $A$. E. R. Taylor and J. R. Baker entitled 'The Cultivation of Parasites in Vitro' published in 1968. Considerable advances have been made since then so that the present work will be an essential laboratory tool for a wide range of researchers in a number of different specialisms including parasitology, entomology, physiology, biochemistry, immunology, cell biology and tropical medicine. The eleven contributors are internationally recognised authorities in their fields and have provided chapters on protozoan and helminth parasites of all groups (including Acanthocephala and nematodes parasitic in plants) and methods of growing parasites in embryonated eggs and in cell or tissue cultures. Each chapter contains a review of the relevant literature since 1968 and full details of the currently important media and techniques. These are preceded by a section written by the editors on general techniques. At the end of the book is an appendix listing names and addresses of all suppliers mentioned in the text. This volume will serve as a comprehensive laboratory handbook, and will also be invaluable as a work of reference for those interested in the development, scope and applications of the in vitro cultivation of parasites.

\section{Academic Press}

London New York San Francisco

A Subsidiary of Harcourt Brace Jovanovich, Publishers

24-28 Oval Road, London NW1, England

111 Fifth Avenue, New York, NY 10003, USA

Australian Office: PO Box 300, North Ryde, NSW 2113, Australia

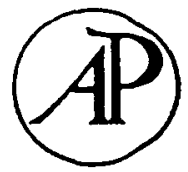




\section{PARASTTOLOGY}




\section{PARASITOLOGY}

(Founded by G. H. F. Nuttall, F.R.S.)

EDITORS

D. W. T. CROMPTON and B. A. NEWTON

EDITORIAL ASSISTANT

M. ELISABETH PAINTER, Ph.D.

ADVISORY BOARD

GWENDOLEN REES, F.R.S. (Chairman)
R. ANDERSON
D. I. GIBSON
M. ELAINE ROSE
D. R. ARTHUR
L. G. GOODWIN, F.R.S.
J. H. ROSE
J. R. BAKER
C. A. HOPKINS
J. F. RYLEY
J. BARRETT
L. P. JOYNER
G. SALT, F.R.S.
ELIZABETH U. CANNING
C. R. KENNEDY
S. R. SMITHERS
ANN M. LACKIE
K. VICKERMAN
L. H. CHAPPELL
D. L. LEE*
D. WAKELIN
S. COHEN
R. J. LINCOLN
P. F. V. WARD
R. R. A. COOMBS, F.R.S.
J. LLE WELLYN
P. J. WHITFIELD
F. E. G. COX
S. H. P. MADDRELL
H. H. WILLI AM S
G. A. M. CROSS
BRIDGET M. OGILVIE
C. A. WRIGHT

* Representing the British Society for Parasitology

V OLUME 77, 1978

CAMBRIDGE UNIVERSITY PRESS

CAMBRIDGE - LONDON - NEW YORK 


\section{PUBLISHED BY}

THE SYNDICS OF THE CAMBRIDGE UNIVERSITY PRESS

The Pitt Building, Trumpington Street, Cambridge CB2 1R.P

Bentley House, 200 Euston Road, London NW1 2DB

32 East 57th Street, New York, N.Y. 10022

(C) Cambridge University Press, 1978 


\title{
CONTENTS
}

\author{
(All rights reserved)
}

\section{Part 1 Adgudst 1978}

DUbeY, J. P. Life-cycle of Isopora ohioensis in dogs . $\quad$. $\quad$. $\quad$. $\quad$. 1

Stromberg, P. C., Toussant, M. J. and Dubey, J. P. Population biology of Paragonimus kellicotti metacercariae in central Ohio . . . . . $\quad$. 13

Fournier, ANNIE. Euzetrema knoepfleri: evidence for a synchronous cycle of the gastrodermal activity and an 'apocrine-like' release of the residues of digestion

Joyner, L. P., Canning, Elizabeth U., Long, P. L., Rollinson, D. and WILliams, R. B. A suggested terminology for populations of coccidia (Eimeriorina), particularly of the genus Eimeria (Protozoa: Apicomplexa)

Ryley, Nicholas G. and Ryley, John F. Effects of saturated sodium chloride solution on coccidial oocysts

Chute, M. B., Chute, Anne M. and Wrikrns, G. C. Effect of dimetridazole on transmission of Histomonas meleagridis by Heterakis gallinarum . .

FrIED, B. and NeLson, P.D. Host-parasite relationships of Zygocotyle lunata (Trematoda) in the domestic chick

Wilson, R. A., Draskau, Tove, Miller, Patricia and Lawson, J. Ruth. Schistosoma mansoni: the activity and development of the schistosomulum during migration from the skin to the hepatic portal system .

Rumjanek, F. D. and Smithers, S. R. Mannosyl transferase activity in homogenates of adult Schistosoma mansoni

Wilson, P. A. G., Cameron, Maureen and Scott, D. S. Patterns of milk transmission of Strongyloides ratti .

Gorr, M. M. and HarPuR, R. P. Aldose reductase and sorbitol dehydrogenase in the muscle of Ascaris suum (Nematoda)

McMa nus, D. P. and Sмryth, J. D. Differences in the chemical composition and carbohydrate metabolism of Echinococcus granulosus (horse and sheep strains) and $E$. multilocularis

Andersen, Karis. The development of the tapeworm Diphyllobothrium latum (L. 1756) (Cestoda: Pseudophyllidea) in its definitive hosts, with special references to the growth patterns of $D$. dendriticum (Nitzsch, 1824) and $D$. ditremum (Creplin, 1827) 


\section{Part 2 OCtober 1978}

Trnsley, R. C. Oviposition, hatching and the oncomiracidium of Eupolystoma anterorchis (Monogenoidea) . . . . . . . . . . . 121

Parshad, V. R. and Guraya, S. S. Morphological and histochemical observations on oocyte atresia in Centrorhynchus corvi (Acanthocephala) .

LÝsEK, H. A scanning electron microscope study of the effect of an ovicidal fungus on the eggs of Ascaris lumbricoides . . . . . . .

Davies, Caroline, Rickard, M. D., Bout, D. T. and Smyth, J. D. Ultrastructural immunocytochemical localization of two hydatid fluid antigens (antigen 5 and antigen $\mathrm{B}$ ) in the brood capsules and protoscoleces of ovine and equine Echinococcus granulosus and $E$. multilocularis

Suswillo, R. R., Denham, D. A., MoGreevy, P. B. and Nelson, G. S. Hybridization between Brugia patei, B. pahangi and sub-periodic B. malayi

Altate, K. I. and Dargie, J. D. Genetic resistance to helminths. The influence of breed and haemoglobin type on the response of sheep to primary infections with Haemonchus contortus

Altate, K. I. and Dargie, J. D. Genetic resistance to helminths. The influence of breed and haemoglobin type on the response of sheep to re-infection with Haemonchus contortus

Anderson, R. M., Whitfield, P. J. and Dobson, A. P. Experimental studies of infection dynamics: infection of the definitive host by the cercariae of Transversotrema patialense . . . . . . . .

Anderson, R. M. Population dynamics of snail infection by miracidia .

Tavares, C. A. P., Soares, Rita C., Coelho, P. M. Z. and Gazzinelli, G. Schistosoma mansoni: evidence for a role of serum factors in protecting artificially transformed schistosomula against antibody-mediated killing in vitro.

Matsuzawa, Toshiakr. Studies on the mode of action of beclotiamine on Eimeria tenella

\section{Part 3 December 1978}

Norton, C. C. and Joyner, L. P. The appearance of bisporocystic oocysts of Eimeria maxima in drug-treated chicks

Fahmy, M. A. M., Abedl-Rahman, A. M. and Khalifa, R. Trypanosoma (Schizotrypanum) assiutis sp.nov. from the house mouse Mus musculus, with a comparative study on Trypanosoma (Schizotrypanum) vespertilionis of the Egyptian bat Vesperugo kuhli 
WARD, P. F. V. and Huskisson, N. S. The energy metabolism of adult Haemonchus contortus, in vitro

Howard, R. J., Christie, P. R., Wakeln, D., Wilson, M. M. and BeHnke, J. M. The effect of concurrent infection with Trichinella spiralis on Hymenolepis microstoma in mice

Meler, Patricia and Wilson, R. A. Migration of the schistosomula of Schistosoma mansoni from skin to lungs .

Bushara, H. O., Hussein, M. F., Saad, A. M., Taylor, M. G., Dargie, J. D., Marshall, T. F. DE C. and Nelson, G. S. Immunization of calves against Schistosoma bovis using irradiated cercariae or schistosomula of $S$. bovis

McLaren, Diane J., Ramalho-Pinto, F. J. and Smithers, S. R. Ultrastructural evidence for complement and antibody-dependent damage to schistosomula of Schistosoma mansoni by rat eosinophils in vitro . .

Bennett, C. E. The identification of soluble adult antigen on the tegumental surface of juvenile Fasciola hepatica . . . . . . . .

Deans, J. A., Dennis, E. D. and Cohen, S. Antigenic analysis of sequential erythrocyte stages of Plasmodium knowlesi . • . . . . .

MILler, F. W. and Ilan, JUDITH. The ribosomes of Plasmodium berghei: isolation and ribosomal ribonucleic acid analysis . . . . . .

Gordon, R., Condon, W. J., Edgar, W. J. and Babie, Sally J. Effects of mermithid parasitism on the haemolymph composition of the larval blackflies Prosimulium mixtum/fuscum and Simulium venustum . .

Samish, M. and PIPano, E. Development of infectivity in Hyalomma detritum (Schulze, 1919) ticks infected with Theileria annulata (Dchunkowsky and Luhs, 1904) .

Proceedings of the British Society for Parasitology, 5-7 April 1978 . . . i 


\section{PARASITOLOGY}

SC B SCRIPTIONs may be sent to any bookseller or subseription agent or direct to Cambridge University Press, P.O. Box 110, Cambridge CB2 3RL. Subscriptions in the U.S.A. and Canada should be sent to Cambridge University Press, 32 East 57th Street, New York, N.Y. 10022. The subscription price of volumes 78 and 79, 1979, is $\$ 21.00$ net (including postage) for a volume of three parts (US $\$ 52.50$ in the U.S.A. and Canada) payable in advance ( $\$ 42.00$ or US $\$ 105.00$ per year); separate parts cost $£ 9.00$ net or US $\$ 22.50$ each (plus postage).

BACK volumes. Vols. 1-39: Inquiries should be addressed to Wm. Dawson \& Sons Ltd, Cannon House, Folkestone, Kent. Vols. 40 onwards: quotations for parts still in print may be obtained from the Cambridge or New York offices of the Cambridge University Press.

COPYING. This journal is registered with the Copyright Clearance Center, New York. Organizations in the U.S.A. who are also registered with C.C.C. may therefore copy material (beyond the limits permitted by sections 107 and 108 of U.S. c law) subject to payment to C.C.C. of the per-copy fee indicated in the code on the first page of the article. This consent does not extend to multiple copying for promotional or commercial purposes.

is i tear service, 325 Chestnut Street, Philadelphia, Pennsylvania 19106, U.S.A., is authorized to supply single copies of separate articles for private use only.

FOR ALL OTHER USE, permission should be sought from the Cambridge or New York offices of the Cambridge University Press.

CLAIMS for missing issues can only be considered if made immediately after receipt of the subsequent issue.

ADVertising. Details of advertising in Parasitology may be obtained from the publisher.

The previous part was published on 4 December 1978 


\section{PARASITOLOGY}

Volume 78, Part 1, February 1979

\section{GONTENTS}

Moreno, M. SANCHEZ and BARRETt, J. Monoamine oxidase in adult Hymenolepis diminuta (Cestoda)

HEALY, J. A. Phosphoglucomutase polymorphism in the tick Ixodes ricinus

PAGE

SCHILDKNECHT, E. G. and SQUזBB, R. L. The effect of vitamins A, E and K on experimentally induced histomoniasis in turkeys

PANTTZ, E. Efficacy and cross-resistance studies on $N, N^{\prime}$-bis $(3,4$ ditrifluoromethylphenyl) methylmalonamide, a novel anticoccidial agent

Long, P. L. and MmLARD, B. J. Studies on Eimeria dispersa Tyzzer 1929 in turkeys

RILEY, J., JAmes, J. L. and BANaJA, A. A. The possible role of the frontal and sub. parietal gland systems of the pentastomid Reighardia sternae (Diesing, 1864) in the evasion of the host immune response

Langhorne, J. and Cohen, S. Plasmodium knowlesi in the marmoset (Callithrix jacchus)

Bomford, R. and McHARdy, N. Corynebacterium parvum as an adjuvant for Trypano. soma cruzi epimastigote vaccines: a comparison with saponin and Bordetella pertussis

Kipnis, T. L., CaLioh, V. L. G. and Dias da Silva, W. Aetive entry of bloodstream forms of Trypanosoma cruzi into macrophages

Higangs, J. C. The role of the tegument of the metacercarial stage of Bucephalus haimeanus (Lacaze-Duthiers, 1854) in the absorption of particulate material and small molecules in solution

The Pitt Building, Trumpington Street, Cambridge CB2 1RP

Bentley House, 200 Euston Road, London NW1 2DB

32 East 57th Street, New York, N.Y. 10022

Printed in Great Britain at the University Press, Cambridge 